\title{
Menyoal Produktivitas Industri Kecil dan Menengah (IKM)
}

\author{
Muhammad Hosni Isnaeni Alna ${ }^{1}$, \\ Suharwan Hamzah ${ }^{2}$ \\ Rahmatia $^{3}$ \\ 1,2,3 Departemen Ilmu Ekonomi FEB Unhas \\ Jl. Perintis Kemerdekaan Km. 10 Tamalanrea \\ E-mail : suharwanhamzah@gmail.com
}

\begin{abstract}
Abstrak:Menyoal Produktivitas Industri Kecil Dan Menengah (IKM)
\end{abstract}

Mendorong perkembangan IKM merupakan salahsatu langkah yang tepat dalam menjaga fundamental ekonomi. Namun, industri nasional pada umumnya diperhadapkan dengan produktifitas tenaga kerja yang rendah, termasuk yang di Kabupaten Barru. Hal tersebut, mengkonfirmasi nilai produktivitas tenaga kerja IKM di Kabupaten Barru begitu rendah, menjadikan salah satu penyebab memburuknya nilai produksi IKM di Kabupaten Barru, yang memposisikan daerah ini sebagai daerah dengan produktifitas tenaga kerja tiga terendah di Sulawesi Selatan. Penelitian ini bertujuan untuk mengetahui pengaruh modal, upah, dan pelatihan terhadap produktivitas Industri Kecil dan Menengah di Kabupaten Barru, dimana produktivitas yang dimaksud dalam penelitian ini adalah produktivitas tenaga kerja. Data yang digunakan dalam penelitian ini adalah data primer dan data sekunder. Data primer diperoleh dari hasil wawancara sebanyak 69 responden dan data sekunder diperoleh dari Dinas Koperasi dan UKM Provinsi Sulawesi Selatan, Bappeda Provinsi Sulawesi Selatan dan publikasi Badan Pusat Statistik (BPS) Kabupaten Barru. Data dianalisis menggunakan regresi berganda dengan pendekatan "ordinary least square" (OLS). Hasil penelitian menunjukkan bahwa Modal berpengaruh positif dan signifikan terhadap Produktivitas Industri Kecil dan Menengah (IKM) di Kabupaten Barru. Upah tidak berpengaruh terhadap Produktivitas Industri Kecil dan Menengah (IKM) di Kabupaten Barru. Pelatihan berpengaruh negatif dan signifikan terhadap Produktivitas Industri Kecil dan Menengah (IKM) di Kabupaten Barru.

Kata Kunci: Produktivitas, Modal, Upah, Pelatihan

\section{Abstract:Questioning Productivity Of Small And Medium Industries}

Encouraging the development of SMEs is one of the right steps in maintaining economic fundamentals. However, the national industry is generally faced with low labor productivity, including those in Barru District. This, confirming the value of SME productivity in Barru Regency is so low that it causes one of the worsening of IKM production value in Barru District, which positions this area as the lowest labor productivity region in South Sulawesi.On This research aims to know the influence of Capital, Wage, and Training on the productivity of Small and Medium Industries in District Barru, where productivity meaning in this research is labor productivity. The data used in this research is primary data and secondary data. The primary data was obtained from interviews of 69 respondents and thn 
secondary data was obtained from Dinas Koperasi dan UKM of South Sulawesi Province, Bappeda of South Sulawesi Province, and publication of Badan Pusat Statistik (BPS) of District Barru. Data were analyzed by using multiple regression approach to "ordinary least square" (OLS). The results showed that capital are positive and significant impact on the productivity of Small and Medium Industries in District Barru. Wage is not significant impact on the productivity of Small and Medium Industries in District Barru. Training are negative and significant impact on the productivity of Small and Medium Industries in District Barru.

Keywords: Productivity, Capital, Wage, Training

\section{PENDAHULUAN / INTRODUCTION}

Struktur ekonomi Indonesia saat ini didorong ke arah sektor industri. Hal ini dikarenakan struktur ekonomi yang berbasis sektor agraris hanya akan menghasilkan nilai produksi yang kecil. Ketika berada pada area ekonomi global, negara hanya akan berperan dalam pemasok bahan baku sekaligus konsumen "produk jadi" dari negara lain, sehingga mendorong perkembangan IKM merupakan langkah yang tepat dalam menjaga fundamental ekonomi, sekaligus menjaga posisi Indonesia dalam konstelasi ekonomi global. Namun, industri nasional pada umumnya diperhadapkan dengan produktifitas tenaga kerja yang rendah, termasuk di Sulawesi Selatan. Dari 24 kabupaten kota yang di Sulawesi Selatan, terdapat tiga kabupaten yang memiliki nilai produksi IKM yang rendah yakni Kabupaten (Wajo, Barru dan Selayar).

Data Nilai Produksi, Jumlah Tenaga Kerja, dan

Produktivitas Tenaga Kerja Industri Kecil dan Menengah (IKM) di Kabupaten Wajo, Barru, Kep. Selayar

\begin{tabular}{cccc}
\hline Kabupaten & $\begin{array}{c}\text { Nilai Produksi } \\
\text { (Rupiah) }\end{array}$ & $\begin{array}{c}\text { Jumlah Tenaga Kerja } \\
\text { (Orang) }\end{array}$ & $\begin{array}{c}\text { Produktivitas Tenaga Kerja } \\
\text { (Nilai Produksi per Tenaga } \\
\text { Kerja) }\end{array}$ \\
\hline Wajo & 4.624 .350 .000 & 135 & $34,254,444$ \\
Barru & 4.602 .100 .000 & 228 & $20,184,649$ \\
Kep. Selayar & 1.720 .561 .000 & 142 & $12,116,627$ \\
\hline
\end{tabular}

Sumber: Bappeda Provinsi Sulawesi Selatan (2016)

Produktivitas tenaga kerja IKM di Kabupaten Barru berada pada kedua terendah. Produktivitas tenaga kerja IKM Kabupaten Wajo sebanyak Rp 34 juta per tenaga kerja, produktivitas tenaga kerja IKM di Kabupaten Barru sebanyak Rp 20 juta per tenaga kerja, dan produktivitas tenaga kerja IKM di Kep. Selayar adalah Rp 12 juta per tenaga kerja. Hal tersebut, mengkonfirmasi nilai produktivitas tenaga kerja IKM di Kabupaten Barru begitu rendah, menjadikan salah satu penyebab memburuknya nilai produksi IKM di Kabupaten Barru. 


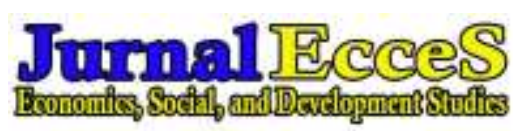

Volume 5 Nomor1 Ed.Juni 2018 : page $80-98$ p-ISSN: 2407-6635 e-ISSN : 2580-5570

Tenaga kerja merupakan salah satu dari tiga faktor produksi yang utama selain tanah dan modal. Produktivitas tenaga kerja dipengaruhi oleh Modal (Yeni dan Budhi, 2016), serta upah dan pelatihan (Yuniasih, Firdaus \& Fahmi, 2013). Modal adalah salah satu faktor produksi yang sangat penting bagi setiap usaha, baik skala kecil, menengah maupun besar (Tulus dalam Afifah, 2012). Dalam memulai suatu usaha, modal merupakan salah satu faktor penting disamping faktor lainnya, sehingga suatu usaha bisa berjalan apabila tersedia modal (Neti dalam Afifah 2012).Selain sebagai bagian terpenting di dalam proses produksi, modal jugamerupakan faktor utama dan mempunyai kedudukan yang sangat tinggi di dalam pengembangan perusahaan (Achmad, dalam Afifah, 2012).

Sistem ekonomi dirancang agar orang bisa mendapat pekerjaan dengan tingkat upah yang layak atau tinggi sehingga taraf hidup masyarakat dapat naik atau sejahtera. Isu distribusi pendapatan (upah) tenaga kerja merupakan isu sensitif yang sering kita dengar di media sebagai isu pertentangan sosial dan perseteruan politis. Tak ayal para calon kepala daerah, legislatif, hingga calon presiden sering menunggangi isu ini sebagai alat untuk mendapatkan simpati dari masyarakat dan rakyat dengan janji-janji program distribusi pendapatan yang berkeadilan saat berkampanye. Upah adalah alasan utama orang saat ini untuk bekerja. Jika tingkat upah tinggi diberikan kepada pekerja, maka akan mendorong pekerja untuk lebih produktif dalam bekerja, begitu pun sebaliknya. Tingkat upah berpengaruh secara positif terhadap produktivitas pekerja (Herdiansyah, 2011). Sistem upah dan bonus adalah syarat bagi produktivitas kerja individu yang tinggi (Sinungan dalam Herdiansyah, 2011).

Selain modal dan upah, yang berpengaruh terhadap produktivitas tenaga kerja adalah pelatihan (Sambodo, 2016). Pendidikan, pengalaman kerja, dan pelatihan-pelatihan akan memberikan tenaga kerja pengetahuan dan skill dalam mengelola usaha dan menjalankan mesin-mesin atau teknologi produksi. Berdasarkan data dan penjelasan yang telah diurai di atas, maka perlu dilakukan suatu kajian yang mendalam dan berkelanjutan yang menganalisis akar permasalahan produktivitas industri kecil dan menengah (IKM) di Kabupaten Barru.

Rendahnya nilai produksi IKM Kabupaten Barru, kemudian dapat ditinjau lewat produktivitas tenaga kerjanya. Dengan bersandar pada pendekatan bahwa produktivitas tenaga kerja dipengaruhi oleh modal, upah, dan pelatihan, maka rumusan masalah penelitian ini adalah sebagai berikut: 1). apakah modal berpengaruh terhadap produktivitas industri kecil dan menengah (IKM) di Kabupaten di Barru, 2). apakah upah berpengaruh 
terhadap produktivitas industri kecil dan menengah (IKM) di Kabupaten Barru?, 3). apakah ada perbedaan produktivitas industri kecil dan menengah (IKM) menurut pelatihan tenaga kerja IKM di Kabupaten di Barru?.

\section{TINJAUAN TEORITIK / LITERATURE REVIEW}

\section{Industri Kecil dan Menengah}

Definisi IKM merujuk pada definisi UMKM sendiri yang diatur dalam UU Nomor 20 Tahun 2008. Menurut UU tersebut, kriteria IKM (UMKM) didasarkan pada kekayaan bersih dan hasil penjualan, yaitu sebagai berikut: (a) Usaha Mikro merupakan usaha memiliki kekayaan bersih paling banyak Rp50.000.000 tidak termasuk tanah dan bangunan tempat usaha; atau memiliki hasil penjualan tahunan paling banyak Rp 300.000.000; (b) Usaha Kecil merupakan usaha yang memiliki kekayaan bersih lebih dari Rp 50.000.000 sampai dengan paling banyak Rp 500.000.000 tidak termasuktanah dan bangunan tempat usaha; atau memiliki hasil penjualan tahunan lebih dari Rp 300.000.000 sampai dengan paling banyak Rp 2.500.000.000; (c) Usaha Menengah merupakan usaha yang memiliki kekayaan bersih lebih dari Rp 500.000.000 sampai dengan paling banyak Rp 10.000.000.000 tidak termasuk tanah dan bangunan tempat usaha; atau memiliki hasil penjualan tahunan lebih dari Rp 2.500.000.000 sampai dengan paling banyak Rp 50.000.000.000.

Definisi khusus mengenai IKM yang dijelaskan oleh BPS adalah sebagai berikut: (a) industri rumah tangga: jumlah tenaga kerja 1-4 orang; (b) industri kecil: jumlah tenaga kerja 5-19 orang; (c) industri sedang atau menengah: jumlah tenaga kerja 20-99 orang; (d) industri besar: jumlah tenaga kerja lebih dari 99 orang.

\section{Tenaga Kerja}

Tenaga kerja menurut UU No. 13 tahun 2003 tentang Ketenagakerjaan adalah setiap orang yang mampu melakukan pekerjaan baik guna menghasilkan jasa dan atau barang untuk memenuhi kebutuhan sendiri maupun untuk masyarakat. Tenaga kerja merupakan penduduk yang dapat diikutsertakan dalam proses ekonomi. Tenaga kerja adalah penduduk yang telah memasuki usia kerja, baik yang sudah bekerja maupun aktif mencari kerja, yang masih mau dan mampu untuk melakukan pekerjaan. Tenaga kerja merupakan faktor produksi yang sangat penting bagi setiap negara di samping faktor alam dan faktor modal. Tenaga kerja adalah setiap orang yang mampu melakukan pekerjaan guna menghasilkan barang dan jasa, baik untuk memenuhi kebutuhan sendiri maupun untuk masyarakat. 


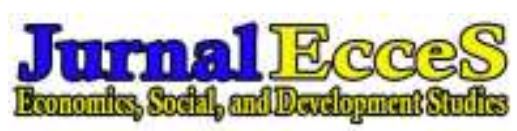

Volume 5 Nomor1 Ed.Juni 2018 : page 80-98 p-ISSN: 2407-6635 e-ISSN : 2580-5570

\section{Teori Produksi dan Produktivitas}

Dalam pandangan Adam Smith dalam banyak tulisannya, memberikan cukup banyak perhatian atas konsep produktivitas, khsususnya produktivitas tenaga kerja. Menurutnya, produktivitas tenaga kerja dapat ditingkatkan melalui pembagian kerja (division of labour) (Deliarnov, 2012). Dengan adanya pembagian kerja, akan berdampak pada terbentuknya spesialisasi. Terbentuknya spesialisasi mendorong orang cukup menghasilkan satu jenis barang saja yang sesuai dengan bakat dan kemampuannya masing-masing, kelebihan barang atas kebutuhan sendiri itu kemudian dipertukarkan (diperdagangkan) di pasar atau biasa juga disebu dengan (nilai tukar). Dengan adanya spesialisasi, hasil produksi secara total akan meningkat sehingga produktivitas juga ikut meningkat. Dalam The Wealth of Nations, Adam Smith menganalogikan konsep produktivitas tenaga kerja dalam proses pembuatan peniti. Sedangkan fungsi produksi menentukan output maksimum yang dapat dihasilkan dari sejumlah input tertentu. Fungsi produksi merupakan suatu cara yang digunakan untuk mendeskripsikan kemampuan produksi suatu usaha. Terdapat tiga konsep penting dalam fungsi produksi, yaitu produk total, produk marjinal, dan produk rata-rata. Produk total adalah jumlah total output yang diproduksi dalam satuan unit. Produk marjinal adalah tambahan output yang dihasilkan dengan menambah satu unit input, sementara input-input yang lainnya tetap. Produk rata-rata adalah hasil bagi dari output total dengan input total.

Namun pandangan itu ditentang mashab ekonomi Marxisme. Terdapat perbedaan ukuran hasil produksi antara mazhab ekonomi kapitalisme/konvensional ala Adam Smith dan mazhab ekonomi Marxisme. Dalam konteks produktivitas, ukuran hasil produksi perspektif ekonomi Marxis adalah nilai-pakai, sedangkan ukuran hasil produksi perspektif ekonomi konvensional adalah nilai-tukar. Nilai-pakai adalah nilai sebuah komoditas sebagai pemenuh kebutuhan manusia, sedangkan nilai-tukar adalah nilai sebuah komoditas untuk ditukar dengan komoditas lain secara umum. Satuan nilai-pakai adalah satuan fisik dari komoditas, seperti 3 buah kursi, 9 meter kabel, dll. Sedangkan satuan nilai-tukar adalah satuan mata uang, seperti Rp 100, 500 euro, dll. Marxisme berasumsi bahwa setiap tambahan nilai produksi yang diproduksi oleh kelas pekerja atau buruh, maka disitu ada nilai produktifitas yang dihisap oleh pemilik modal dari kelas pekerja, yang seharusnya dilimpahkan ke kelas pekerja, sebab yang menciptakan sebuah nilai terhadap sebuah barang adalah kelas pekerja. Dengan demikian, semakin banyak pekerja yang bekerja dalam suatu proses 
produksi, maka semakin besar nilai produktifitas dan tingkat kesejahteraan yang harus didapatkan oleh pekerja itu sendiri.

Namun, hal tersebut diluruskan oleh teoritikus neoklasik yang menyatakan bahwa yang menentukan dalam proses produksi adalah bukanlah jumlah pekerja yang ada. Namun, ditentukan oleh nilai produktifitas dari seorang pekerja. Dari fungsi produksi, dikenallah suatu hukum ekonomi yaitu The Law of Diminishing Returns (hukum penambahan hasil yang semakin berkurang). Hukum ini menyatakan bahwa tambahan output yang dihasilkan dari menambahkan suatu input tertentu akan semakin berkurang ketika penambahan suatu input tersebut dilakukan terus menerus sementara input yang lainnya tetap atau konstan. Dengan kata lain, produk marjinal dari tambahan suatu input akan mengalami penurunan meskipun jumlah suatu input bertambah sementara jumlah input yang lainnya konstan. Oleh karena kecenderungan sistem ekonomi mengarah pada ekspansi nilai tukar, maka definisi produktivitas yang dipakai dalam penelitian ini adalah produktivitas yang berdasarkan pada nilai tukar. Definisi tersebut bisa dilihat dari pendapat Samuelson dan Nordhaus (2003) yang mengatakan bahwa produktivitas adalah suatu konsep yang mengukur rasio dari total output terhadap rata-rata tertimbang dari input, dimana varian produktivitas itu sendiri terdiri atas produktivitas tenaga kerja yang diukur dengan menghitung jumlah output per unit tenaga kerja dan produktivitas faktor produksi total yang diukur dengan output per agregat dari total input (biasanya modal dan tenaga kerja).

\section{Modal}

Menurut Mankiw (dalam Mustofa, 2013), modal adalah segenap peralatan dan fasilitas dasar/struktur yang digunakan dalam kegiatan produksi, artinya modal yang dimiliki oleh sebuah perekonomian meliputi semua barang yang diproduksi di masa lalu yang sekarang digunakan untuk memproduksi atau mendapatkan barang dan jasa. Mubyarto (dalam Afifah, 2012) memberikan definisi modal sebagai sumber-sumber ekonomi di luar tenaga kerja yang dibuat oleh manusia, kadang-kadang modal dilihat dalam arti uang atau dalam arti keseluruhan nilai sumber-sumber ekonomi non-manusiawi termasuk tanah.

\section{Upah}

Lahirnya teori nilai lebih berdasar dari teori nilai Adam Smith dan David Ricardo yang menyatakan bahwa nilai suatu barang ditentukan oleh nilai tenaga kerja yang dikorbankan untuk menghasilkan barang tersebut. Jika teori tersebut dijalankan, seharusnya seluruh hasil produksi milik tenaga kerja. Akan tetapi, dalam kenyataannya tenaga kerja tidak memperoleh upah sebesar nilai yang dikorbankan untuk menghasilkan suatu barang. Ada nilai lebih yang ditahan oleh pemilik modal sebagai laba bagi dirinya, yang kemudian 


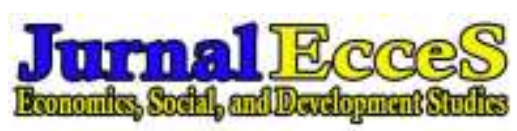

Volume 5 Nomor1 Ed.Juni 2018 : page 80-98 p-ISSN: 2407-6635 e-ISSN : 2580-5570

menggambarkan tingkat eksploitasi tenaga kerja/buruh. Alhasil dengan adanya nilai lebih yang ditahan oleh pemilik modal, fenomena penindasan atau perbudakan dalam konteks modern terjadi di mana-mana. Misalnya, fenomena buruh sepatu yang menghasilkan satu sepatu seharga puluhan juta, justru tidak mampu dibeli sendiri oleh buruh yang notabene pembuat sepatu tersebut.

Dari penjelasan di atas, dapat disimpulkan bahwa, secara substansial, upah merupakan ukuran nilai yang dicurahkan pekerja kepada produk/komoditi yang dihasilkannya atau nilai tenaga kerja yang dikorbankan untuk menghasilkan suatu produk/komoditi. Tingkat upah yang diberikan kepada tenaga kerja saat ini ditentukan oleh kekuatan daya beli per satu jam kerja atau upah nominal dibagi dengan biaya hidup per bulan.

\section{Pelatihan}

Tenaga kerja yang terlatih mampu menghasilkan tingkat produktivitas marjinal yang lebih tinggi. Produktivitas marjinal tinggi yang dihasilkan tenaga kerja terlatih merupakan hasil dari investasi pendidikan dan pelatihan yang ia lakukan. Dokter, teknisi, pengacara, dll., misalnya, melakukan investasi selama bertahun-tahun pada pendidikan formal dan pada on-the-job training. Mereka menghabiskan sejumlah besar uang untuk membayar biaya pendidikan dan pelatihannya Hasil dari investasi pelatihan dan pendidikan tersebut adalah kualitas tenaga kerja yang tinggi, sehingga tingkat upah yang diterima pun tinggi.

Pelatihan mampu mengembangkan kualitas dari tenaga kerja. Output dari pelatihan adalah angkatan kerja yang lebih terampil, berpengetahuan, handal, dan sesuai dengan tuntutan pembangunan nasional. Sumber daya alam yang dimiliki oleh suatu negara hanya bisa dikelola oleh tenaga-tenaga kerja yang terdidik atau terlatih.

\section{Hubungan Modal Terhadap Produktivitas}

Masuknya modal ke dalam faktor produksi primer menjadikan posisi modal sangat penting dalam proses produksi. Dalam sebuah usaha, modal (modal fisik dan modal finansial) menentukan permulaan dan perkembangan suatu usaha. Jika tidak ada modal, usaha tidak dapat berdiri. Begitupun dalam perkembangan usaha, jika jumlah modal sedikit, maka perkembangan usaha tidak besar dan jika jumlah modal banyak, maka perkembangan usaha tersebut berpotensi besar.

Perkembangan suatu usaha dalam hal ini perluasan cakupan ekspansi profit haruslah didukung oleh penambahan input produksi yang proporsional. Penambahan input produksi yang proporsional akan meningkatkan produktivitas usaha. Salah satu input produksi yang 
penting untuk ditingkatkan jumlahnya adalah modal (baik berupa teknologi dan sarana prasana lain maupun modal finansial yang mendukung proses produksi). Teknologi merupakan faktor produksi yang dapat membantu suatu usaha dalam memproduksi ouput secara efektif dan efisien. Dengan adanya modal (barang modal dan modal finansial), akan membantu tenaga kerja dalam meningkatkan hasil produksi. Akan tetapi, peningkatan input modal haruslah proporsional dengan peningkatan input tenaga kerja. Jika salah satunya tidak proporsional, maka mengakibatkan terjadinya produktivitas yang menurun (Antari dan Widanta : 2016).

\section{Hubungan Upah Terhadap Produktivitas}

Produktivitas suatu usaha sangat ditentukan oleh produktivitas tenaga kerjanya. Jika tenaga kerja mampu menghasilkan output yang lebih banyak dari sebelumnya dengan jumlah tenaga kerja yang sama atau lebih rendah dari sebelumnya, maka produktivitas tenaga kerja tersebut meningkat, yang sekaligus juga meningkatkan produktivitas usaha. Tenaga kerja menjadi salah satu faktor primer seperti yang dikemukakan Mankiw (2007). Tenaga kerja bertugas mengelola dan menjalankan mesin-mesin produksi usaha. Sehingga mustahil suatu usaha (saat ini) beroperasi tanpa adanya tenaga kerja.

Selain modal, produktivitas tenaga kerja dipengaruhi oleh tingkat upah. Jika tingkat upah tenaga kerja naik, maka akan menstimulus tenaga kerja lebih produktif dan meningkatkan output. Besar kecilnya upah yang diberikan perusahaan kepada para pekerjanya akan mempengaruhi tinggi rendahnya tingkat produktivitas kerja (Setiadi dalam Adhadika, 2013), seperti pada produktivitas karyawan usaha kerajinan ukir di Kabupaten Subang (Sulaeman, 2014).

\section{Hubungan Pelatihan Terhadap Produktivitas}

Pendidikan juga merupakan faktor yang mempengaruhi produktivitas tenaga kerja. Jika tingkat pelatihan tenaga kerja banyak, maka tenaga kerja tersebut memiliki skill yang baik dalam mengelola atau mengoperasikan mesin-mesin produksi. Hal ini sejalan dengan yang dikemukakan Yuniasih, Firdaus, dan Fahmi (2013) bahwa semakin banyak pelatihan yang dikuti olh tenaga kerja, maka semakin tinggi pula tingkat produktivitas tenaga kerja tersebut.

Pelatihan dapat mememberikan wawasan dan pengetahuan teknis dalam mengelola suatu usaha. Selain itu, pelatihan juga mampu memberikan kesadaran bagi pekerja agar lebih produktif dalam bekerja. Tingginya kesadaran akan pentingnya produktivitas, akan mendorong tenaga kerja yang bersangkutan melakukan tindakan yang produktif (Kurniawan, 2010). 


\section{METODE PENELITIAN / METHODS}

Penelitian ini merupakan penelitian kuantitatif dengan menggunakan jenis data primer dan data sekunder. Data primer bersumber dari observasi dan wawancara langsung pemilik usaha IKM dan data sekunder bersumber dari Bappeda Propinsi Sulawesi Selatan, Badan Pusat Statistik Kabupaten Barru, dan Dinas Koperasi dan UMKM Kabupaten Barru.

Metode pengumpulan data melalui penelitian pustaka dan penelitian lapangan dengan cara observasi dan wawancara.

Populasi dalam penelitian ini adalah seluruh jumlah industri kecil dan menengah di Kabupaten Barru, yaitu sebanyak 69 unit yang tersebar di tujuh kecamatan dan jumlah sampel dalam penelitian ini sama dengan jumlah populasi yaitu 69 unit IKM.

Metode analisis data yang dipakai dalam penelitian ini adalah analisis regresi berganda. Analisis regresi linier berganda dalam penelitian ini digunakan untuk melihat pengaruh modal, upah, dan pelatihan terhadap produktivitas tenaga kerja pada IKM di Kabupaten Barru.

Secara matematis, pengaruh variabel bebas terhadap variabel terikat dapat dilihat dalam persamaan berikut:

$$
Y=f\left(X_{1}, X_{2}, X_{3}\right)
$$

Besarnya pengaruh variabel bebas terhadap variabel terikat ditunjukkan dengan persamaan regresi linier berganda berikut:

$$
Y=a+\beta_{1} X_{1}+\beta_{2} X_{2}+\beta_{3} X_{3}+\mu
$$

Keterangan:

$$
\begin{aligned}
& Y=\text { Produktivitas tenaga kerja pada IKM di Kabupaten Barru } \\
& a=\text { Konstanta } \\
& \beta_{1}, \beta_{2}, \beta_{3} \quad=\text { Koefisien regresi } \\
& X_{1}=\text { Modal } \\
& X_{2}=\text { Upah } \\
& X_{3}=\text { Pelatihan }
\end{aligned}
$$




\section{HASIL DAN PEMBAHASAN / DISCUSSION}

\section{Deskripsi Responden pada Industri Kecil dan Menengah di Kabupaten Barru}

Responden dalam penelitian ini adalah para pemilik usaha IKM yang berada di Kabupaten Barru Provinsi Sulawesi Selatan, yang tersebar di tujuh Kecamatan, yaitu Kecamatan Tanete Riaja, Kecamatan Tanete Rilau, Kecamatan Barru, Kecamatan Soppeng Riaja, Kecamatan Mallusetasi, Kecamatan Pujananting, dan Kecamatan Balusu. Variabel pada penelitian ini yang mempengaruhi produktivitas tenaga kerja industri kecil dan menengah (IKM) di Kabupaten Barru adalah modal, upah, dan pelatihan.

Deskripsi Responden Menurut Modal dan Produktivitas Tenaga Kerja pada Industri Kecil dan Menengah (IKM) di Kabupaten Barru Produktivitas Tenaga Kerja IKM

Modal IKM (dalam (Nilai Produksi per Jumlah Tenaga Kerja) rupiah) 20.000.000 270.000.001$520.000 .001-$

Total

$60.000 .000-$

310.000 .000

$310.000 .001-$

560.000 .000

$560.000 .001-$

810.000 .000

Total 270.000 .000 520.000 .000 770.000 .000

52

1

$-$

9

1

3

13
1

$-$

2

3
62

69

Sumber: Data Primer (2017)

Jika produktivitas tenaga kerja IKM di Kabupaten Barru, diasumsikan, yang paling tertinggi adalah Rp 520.000.001 - Rp 770.000.000 per orang per tahun, sedang adalah Rp 270.000.001 - Rp 520.000.000 per orang per tahun dan yang paling terendah adalah Rp 20.000.000 - Rp 270.000.000 per orang per tahun, maka berdasarkan Tabel 4.10 di atas, menunjukkan bahwa responden dengan kategori tingkat produktivitas tenaga kerja rendah (53 responden atau IKM), didominasi oleh responden atau IKM dengan modal antara Rp 60.000.000 - Rp 310.000.000. Untuk responden dengan kategori tingkat produktivitas tenaga kerja sedang (13 responden atau IKM), didominasi oleh responden atau IKM dengan modal antara Rp 60.000.000 - Rp 310.000.000. Dan untuk responden dengan kategori tingkat produktivitas tenaga kerja tinggi (3 responden atau IKM), di dominasi oleh responden atau IKM dengan modal antara Rp 560.000.001 - Rp 810.000.000.

Dari uraian di atas dapat disimpulkan bahwa terdapat lebih banyak IKM dengan produktivitas tenaga kerja yang lebih rendah dengan nilai modal yang lebih rendah pula 


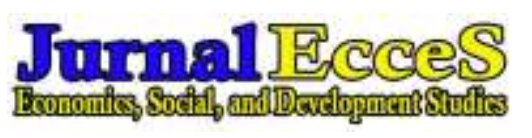

Volume 5 Nomor1 Ed.Juni 2018 : page $80-98$ p-ISSN: 2407-6635 e-ISSN : 2580-5570

serta hanya sedikit IKM yang memiliki produktivitas tenaga kerja yang tinggi dengan nilai modal yang tinggi pula.

Deskripsi Responden Menurut Upah dan Produktivitas Tenaga Kerja pada Industri Kecil dan Menengah (IKM) di Kabupaten Barru

Produktivitas Tenaga Kerja IKM

\begin{tabular}{ccccc}
\hline & \multicolumn{4}{c}{ Produktivitas Tenaga Kerja IKM } \\
Upah (dalam rupiah) & \multicolumn{2}{c}{ (Nilai Proudksi per Jumlah Tenaga Kerja) } & Total \\
& $20.000 .000-$ & $270.000 .001-$ & $520.000 .001-$ & \\
\hline $500.000-1.000 .000$ & 270.000 .000 & 520.000 .000 & 770.000 .000 & 67 \\
$1.000 .001-1.500 .000$ & 53 & 12 & - & 1 \\
$1.500 .001-2.000 .000$ & - & 1 & 1 & 1 \\
Total & - & - & 3 & 69 \\
\hline
\end{tabular}

Sumber: Data Primer (2017)

Jika produktivitas tenaga kerja IKM di Kabupaten Barru, diasumsikan, yang paling tertinggi adalah Rp 520.000.001 - Rp 770.000.000 per orang per tahun, sedang adalah Rp 270.000.001 - Rp 520.000.000 per orang per tahun dan yang paling terendah adalah Rp 20.000.000 - Rp 270.000.000 per orang per tahun, maka berdasarkan Tabel 4.11 di atas, menunjukkan bahwa responden dengan kategori tingkat produktivitas tenaga kerja rendah (53 responden atau IKM), didominasi oleh responden atau IKM dengan tingkat upah yang diberikan kepada tenaga kerjanya antara Rp 500.000 - Rp 1.000 .000 per bulan. Untuk responden dengan kategori tingkat produktivitas tenaga kerja sedang (13 responden atau IKM), didominasi oleh responden atau IKM dengan tingkat upah yang diberikan kepada tenaga kerjanya antara Rp 500.000 - Rp 1.000 .000 per bulan. Dan untuk responden dengan kategori tingkat produktivitas tenaga kerja tinggi (3 responden atau IKM), di dominasi oleh responden atau IKM dengan dengan tingkat upah yang diberikan kepada tenaga kerjanya antara Rp 500.000 - Rp 1.000.000 per bulan pula.

Dari uraian di atas dapat disimpulkan bahwa semua kategori produktivitas tenaga kerja baik itu rendah, sedang, maupun tinggi, didominasi oleh responden atau IKM yang memberikan tingkat upah kepada tenaga kerjanya antara Rp Rp 500.000 - Rp 1.000.000 per bulan. Hal ini menggambarkan pula bahwa tingkat upah yang diberikan kepada tenaga kerja tidak mempengaruhi produktivitas tenaga kerja. Jika produktivitas tenaga kerja IKM di Kabupaten Barru, diasumsikan, yang paling tertinggi adalah Rp 520.000.001 - Rp 770.000.000 per orang per tahun, sedang adalah Rp 270.000.001 - Rp 520.000.000 per orang per tahun dan yang paling terendah adalah Rp 20.000.000 - Rp 270.000.000 per orang per tahun, maka berdasarkan tersebut, menunjukkan bahwa responden dengan kategori tingkat produktivitas tenaga kerja rendah (53 responden atau IKM), didominasi 
Deskripsi Responden Menurut Pelatihan dan Produktivitas Tenaga Kerja pada Industri Kecil dan Menengah (IKM) di Kabupaten Barru

\begin{tabular}{|c|c|c|c|c|}
\hline \multirow{2}{*}{ Pelatihan } & \multicolumn{3}{|c|}{ Produktivitas Tenaga Kerja IKM } & \multirow{3}{*}{ Tot } \\
& \multicolumn{2}{|c|}{ (Nilai Produksi per Jumlah Tenaga Kerja) } & al \\
\cline { 2 - 5 } & $20.000 .000-$ & $270.000 .001-$ & $520.000 .001-$ & 770.000 .000 \\
\\
270.000 .000 & 520.000 .000 & - & 38 \\
\hline Pernah Mengikuti & 33 & 5 & 3 & 31 \\
\hline Tidak Pernah Mengikuti & 20 & 8 & 3 & 69 \\
\hline Total & 53 & 13 & & \\
\hline
\end{tabular}

Sumber: Data Primer (2017)

oleh responden atau IKM yang pernah mengikutkan tenaga kerjanya pelatihan. Untuk responden dengan kategori tingkat produktivitas tenaga kerja sedang (13 responden atau IKM), didominasi oleh responden atau IKM yang tidak pernah mengikutkan tenaga kerjanya pelatihan. Dari uraian di atas, dapat disimpulkan bahwa terdapat lebih banyak IKM yang memiliki produktivitas tenaga kerja yang lebih tinggi, tetapi tidak pernah mengikutkan tenaga kerjanya pelatihan. Dan terdapat lebih banyak IKM yang memiliki produktivitas tenaga kerja yang lebih rendah tetapi pernah mengikutkan tenaga kerjanya pelatihan.

\section{Hasil Estimasi Faktor-Faktor Yang Mempengaruhi Produktivitas Industri Kecil dan Menengah (IKM) di Kabupaten Barru Provinsi Sulawesi Selatan}

Untuk mengetahui pengaruh modal (X1), upah (X2), dan pelatihan (X3) terhadap produktivitas industri kecil dan menengah (IKM) di Kabupaten Barru (Y), dimana produktivitas yang dimaksud adalah produktivitas tenaga kerja, maka disajikan hasil perhitungan regresi yang diperoleh dengan menggunakan pada tabel 4.13 sebagai berikut :

Hasil Estimasi Pengaruh Modal, Upah, dan Pelatihan Terhadap Produktivitas Tenaga Kerja IKM di Kabupaten Barru

\begin{tabular}{lcccc}
\hline Variabel Penelitian & $\begin{array}{c}\text { Unstandarized } \\
\text { Coefficients B }\end{array}$ & $\begin{array}{c}\text { Unstandarized } \\
\text { Coefficients Std. } \\
\text { Error }\end{array}$ & $\mathrm{T}$ & Sig \\
\hline Modal $\left(\mathrm{X}_{1}\right)$ & 0,557 & 0,101 & 5,523 & 0,000 \\
Upah $\left(\mathrm{X}_{2}\right)$ & 0,251 & 0,275 & 0,910 & 0,366 \\
Pelatihan $\left(\mathrm{X}_{3}\right)$ & $-0,303$ & 0,117 & $-2,584$ & 0,012 \\
\hline C & 5,442 & 3,269 & 1,665 & 0,101 \\
R- Squared $=0,514$ & Adjusted R-Squared & $=0,491 \mathrm{n}=69$ & & \\
F- Statistic $=22,899$ Sig $=0,000$ & & & \\
Ket* Signifikan pada a $=5 \%$ & & & \\
\hline
\end{tabular}

Sumber: Data Primer, setelah diolah (2018) 


\section{JurnalIE.eSeS}

Volume 5 Nomor1 Ed.Juni 2018 : page 80-98 p-ISSN: 2407-6635 e-ISSN : 2580-5570

Hasil analisis regresi di atas, mengenai pengaruh modal (X1), upah (X2), pelatihan (X3) terhadap produktivitas IKM (Y) di Kabupaten Barru adalah :

$\operatorname{Ln} Y=5,442+0,557 \operatorname{Ln} X 1+0,251 \operatorname{Ln} X 2-0,303$ X3

Berdasarkan pada Tabel 4.13, dengan melihat koefisien regresi, diketahui bahwa nilai koefisien modal adalah 0,557 yang berarti bahwa setiap kenaikan 1 persen variabel X1 (modal), akan berpengaruh positif sebesar 55,7 persen terhadap peningkatan variabel $Y$ (produktivitas IKM). Selain itu, diketahui nilai sig-nya kurang dari taraf signifikansi 5\% $(0,05)$, yaitu 0,000. Jadi, dapat disimpulkan bahwa modal berpengaruh positif secara signifikan terhadap produktivitas industri kecil dan menengah (IKM) di Kabupaten Barru (variabel Y).

Upah memiliki nilai koefisien sebesar 0,251. Akan tetapi, diketahui nilai sig-nya lebih dari taraf signifikansi 5\% $(0,05)$ yaitu 0,366. Jadi, dapat disimpulkan bahwa upah (variabel X2) berpengaruh positif tetapi tidak signifikan terhadap produktivitas industri kecil dan menengah (IKM) di Kabupaten Barru (variabel Y).

Hasil uji statistik memperlihatkan bahwa pelatihan memiliki nilai koefisien -0,303. Selain itu, diketahui nilai sig-nya kurang dari taraf signifikansi $5 \%(0,05)$, yaitu 0,012 . Jadi, dapat disimpulkan bahwa ada perbedaan antara tenaga kerja yang ikut pelatihan dan tidak ikut pelatihan.

\section{Uji Koefisien Determinasi $\left(\mathbf{R}^{2}\right)$}

Dari hasil regresi pada tabel 4.13 mengenai pengaruh modal (X1), upah (X2), pelatihan (X3) terhadap produktivitas tenaga kerja IKM ( $\mathrm{Y}$ ) di Kabupaten Barru diperoleh $\mathrm{R}^{2}$ dengan nilai sebesar 0,514 . Hal ini berarti variabel-variabel independen yaitu modal (X1), upah (X2), pelatihan (X3) menjelaskan besarnya proporsi sumbangan pengaruh terhadap produktivitas IKM (Y) di Kabupaten Barru adalah sebesar 51,4 persen. Adapun sisanya, pengaruh variabel yang lain dijelaskan diluar model sebesar 48,6 persen.

\section{Uji Statistik F}

Pengujian terhadap semua variabel independen di dalam model dapat dilakukan dengan Uji F. Pengaruh modal (X1), upah (X2), pelatihan (X3) terhadap produktivitas IKM (Y) di Kabupaten Barru dengan menggunakan taraf keyakinan 95\% $(a=0.05)$, didapatkan f-tabel ( $d f 1=k-1=4-1=3$ dan df2 =n-k = 69-4 = 65) sebesar 2,75. Sedangkan dari hasil regresi pada tabel 4.13 diperoleh F-statistik sebesar 22,899. Dapat diketahui bahwa hasil estimasi pada tabel 4.13, F-statistik lebih besar dari F-tabel dan juga nilai sig-nya kurang dari taraf signifikansi $5 \%$ yaitu, $0.000<0.05$. Sehingga dapat disimpulkan bahwa secara 
bersama-sama, variabel modal, upah, pelatihan berpengaruh signifikan terhadap produktivitas IKM di Kabupaten Barru.

\section{Hasil Analisis Faktor-Faktor Yang Mempengaruhi Produktivitas Industri Kecil dan Menengah (IKM) di Kabupaten Barru Provinsi Sulawesi Selatan}

Berdasarkan hasil estimasi dan analisis data di atas, selanjutnya dilakukan penjabaran implikasi atas faktor-faktor yang mempengaruhi produktivitas (dimana produktivitas yang dimaksud adalah produktivitas tenaga kerja) industri kecil dan menengah (IKM) di Kabupaten Barru, Provinsi Sulawesi Selatan. Adapun penjabaran yang dimaksud beserta temuan dari penelitian sebelumnya adalah sebagai berikut:

\section{Pengaruh Modal Terhadap Produktivitas Industri Kecil dan Menengah (IKM) di Kabupaten Barru.}

Berdasarkan hasil dari regresi yang telah dilakukan pada Tabel 4.13, diketahui bahwa nilai koefisien modal adalah 0,557 dan diketahui nilai sig-nya kurang dari taraf signifikansi $5 \%(0,05)$, yaitu 0,000 yang berarti bahwa variabel modal berpengaruh secara signifikan dan positif terhadap produktivitas industri kecil dan menengah (IKM). Artinya, setiap kenaikan 1 persen variabel X1 (modal), akan berpengaruh positif atau menyebabkan peningkatan variabel $Y$ (produktivitas IKM) sebesar 55,7 persen. Diketahui juga bahwa variabel modal (X1) memiliki t-statistik sebesar 5,523. Yang berarti bahwa variabel modal memiliki koefisien yang signifikan terhadap produktivitas tenaga kerja IKM (Y)Jadi, dapat disimpulkan bahwa modal berpengaruh positif dan signifikan terhadap produktivitas industri kecil dan menengah (IKM) di Kabupaten Barru.

Hal ini membuktikan bahwa produktivitas industri kecil dan menengah (dalam hal ini produktivitas tenaga kerja IKM) dapat ditingkatkan lewat peningkatan modal. Artinya, jika modal meningkat, maka produktivitas IKM dapat meningkat pula. Pengaruh modal terhadap produktivitas IKM di Kabupaten Barru yang positif, pada hasil penelitian ini, mendukung hipotesis yang penulis buat sebelumnya pada bab 2 yang menyatakan bahwa modal berpengaruh positif terhadap produktivitas industri kecil dan menengah di Kabupaten Barru.

Hasil dari penelitian ini sesuai dengan Yeni dan Budhi (2016) yang menyatakan bahwa modal berpengaruh positif dan signifikan terhadap produktivitas kerja patung kayu di Kabupaten Badung.

Seperti yang telah dijelaskan sebelumnya, bahwa faktor produksi primer adalah modal dan tenaga kerja. Dalam memproduksi komoditas diperlukan kombinasi kedua faktor produksi ini. Adanya pengaruh positif antara modal dengan produktivitas IKM, disebabkan 


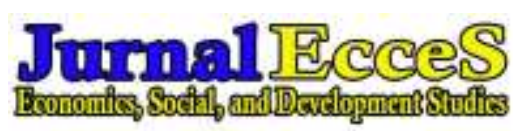

Volume 5 Nomor1 Ed.Juni 2018 : page 80-98 p-ISSN: 2407-6635 e-ISSN : 2580-5570

oleh penambahan atau peningkatan modal akan memberikan tambahan ruang bagi tenaga kerja dalam memproduksi output lebih banyak.

Meningkatnya modal berarti pula meningkatkan alat-alat produksi (barang modal), baik dalam segi kualitas (misalnya meng-upgrade alat produksi ke yang lebih modern) maupun dalam segi kuantitas (misalnya menambah unit alat produksi). Alat-alat produksi yang lebih modern akan menghasilkan output yang lebih banyak secara efisien, begitu pun apabila menambahkan unit alat-alat produksi. Misalnya menambah unit alat pengolahan limbah plastik, akan menghasilkan output yang lebih banyak dari sebelum alat pengolahan limbah plastik ditambah. Dengan adanya alat produksi yang lebih modern atau bertambahnya unit alat produksi, maka tenaga kerja dapat menghasilkan output lebih banyak dari sebelumnya yang berarti pula bahwa produktivitasnya meningkat.

Akan tetapi, penambahan modal haruslah proporsi dengan penambahan input lainnya, sebab jika hanya modal yang terus ditingkatkan atau ditambahkan sementara input produksi yang lain tidak bertambah atau konstan, maka produksi akan sampai pada satu titik dimana ketidakefisienan terjadi. Hal ini dikarenakan akan tercipta ruang di mana tenaga kerja tidak mampu mengelola modal yang ada sebab jumlah modal dan tenaga kerja sangat timpang. Akan ada modal yang "menganggur".

\section{Pengaruh Upah Terhadap Produktivitas Industri Kecil dan Menengah (IKM) di Kabupaten Barru}

Berdasarkan hasil dari regresi yang telah dilakukan pada Tabel 4.13, diketahui bahwa nilai koefisien upah adalah 0,251 dan diketahui nilai sig-nya lebih besar dari taraf signifikansi $5 \%(0,05)$, yaitu 0,366 yang berarti bahwa variabel modal tidak signifikan terhadap produktivitas industri kecil dan menengah (IKM). Artinya, setiap kenaikan atau penurunan variabel X2 (upah), tidak akan berpengaruh terhadap variabel $\mathrm{Y}$ (produktivitas IKM). Variabel upah (X2) memiliki t-statistik sebesar 0,910. Sehingga disimpulkan bahwa variabel upah memiliki koefisien yang tidak signifikan terhadap produktivitas IKM (Y). Dengan demikian, hasil estimasi ini tidak sesuai dengan hipotesis bahwa upah berpengaruh positif terhadap produktivitas industri kecil dan menengah (IKM) di Kabupaten Barru.

Tidak signifikannya pengaruh upah terhadap produktivitas tenaga kerja IKM di Kabupaten Barru, disebabkan oleh masih rendahnya harga kebutuhan hidup di Kabupaten Barru. Artinya, meskipun tenaga kerja diberikan upah dengan nilai yang masih di bawah UMR, mereka masih bisa memenuhi kebutuhan dasar hidupnya dan merasa cukup dengan upah yang diberikan. Sehingga upah tidak akan berpengaruh meski tenaga kerja mampu 
menghasilkan tingkat produktivitas yang tinggi. Akan tetapi, meskipun mereka masih mampu memenuhi kebutuhan dasar hidupnya dengan upah di bawah UMR, tetap saja hak tenaga kerja yang harusnya diberikan tidak terpenuhi. Sudah menjadi kewajiban pemilik usaha untuk memberikan upah yang layak bagi pekerjanya.

Selain itu, rendahnya kesadaran tenaga kerja akan gap antara upah yang diberikan oleh pemilik IKM dengan upah yang seharusnya dia terima atas besaran nilai produksi yang dia hasilkan, turut menjadi penyebab upah tidak mempengaruhi produktivitas tenaga kerja IKM di Kabupaten Barru. Latar belakang pendidikan tenaga kerja menjadi penyebab ketidaktahuan tenaga kerja akan adanya gap tersebut.

\section{Pengaruh Pelatihan Terhadap Produktivitas Industri Kecil dan Menengah (IKM) di Kabupaten Barru.}

Berdasarkan hasil dari regresi yang telah dilakukan pada Tabel 4.13, diketahui bahwa nilai koefisien modal adalah -0,303 dan diketahui nilai sig-nya kurang dari taraf signifikansi $5 \%(0,05)$, yaitu 0,012 . Variabel pelatihan memiliki t-statistik sebesar 2,584. yang berarti bahwa variabel pelatihan berpengaruh negatif dan signifikan terhadap produktivitas industri kecil dan menengah (IKM). Hal ini berarti bahwa ada perbedaan antara tenaga kerja yang pernah mengikuti pelatihan dan tidak pernah mengikuti pelatihan. Adanya perbedaan antara tenaga kerja yang pernah mengikuti pelatihan dengan tenaga kerja yang tidak pernah mengikuti pelatihan, pada hasil penelitian ini, mendukung hipotesis yang penulis buat sebelumnya pada bab 2 yang menyatakan bahwa diduga ada perbedaan produktivitas industri kecil dan menengah (IKM) menurut pelatihan tenaga kerja IKM di Kabupaten Barru.

Hal ini membuktikan bahwa tenaga kerja yang tidak mengikuti pelatihan memiliki produktivitas yang lebih tinggi dibandingkan dengan tenaga kerja yang mengikuti pelatihan. Hal ini disebabkan oleh materi yang disajikan dalam pelatihan sangat monoton, tidak mampu menjawab tantangan pasar saat ini, sebagian besar pelatihan hanya diperuntukkan pada IKM yang bergerak pada sektor pangan, serta tidak adanya follow up setelah pelatihan diadakan, menyebabkan pelatihan tidak memberikan dampak yang positif terhadap produktivitas IKM. Tenaga kerja yang memiliki produktivitas yang tinggi justru lahir dari pembelajaran kultural dan pengalaman kerja, bukan dalam bentuk pelatihan formal. Oleh karena basis produksi IKM berasal dari sumber daya lokal, maka pada dasarnya, pelatihan yang baik bagi tenaga kerja IKM adalah dengan mengasah skillnya lewat bersentuhan langsung dengan basis produksinya, secara kultural dan internal. 


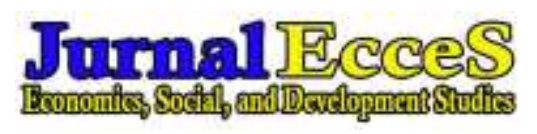

Volume 5 Nomor1 Ed.Juni 2018 : page $80-98$ p-ISSN: 2407-6635 e-ISSN : 2580-5570

\section{KESIMPULAN / CONCLUSION}

Berdasarkan hasil penelitian yang telah dilakukan, dapat diambil kesimpulan dari penelitian ini adalah sebagai berikut :

Modal berpengaruh positif terhadap produktivitas industri kecil dan menengah (IKM) di Kabupaten Barru. Artinya, jika modal ditingkatkan, maka ikut meningkatkan produktivitas industri kecil dan menengah (IKM) di Kabupaten Barru.

Upah tidak berpengaruh terhadap produktivitas industri kecil dan menengah (IKM) di Kabupaten Barru. Artinya peningkatan atau penurunan upah tidak akan mempengaruhi produktivitas industri kecil dan menengah (IKM) di Kabupaten Barru.

Terdapat perbedaan antara industri kecil dan menegah (IKM) yang pernah mengikutkan tenaga kerjanya pelatihan dengan IKM yang tidak pernah mengikutikan tenaga kerjanya pelatihan. IKM yang tidak mengikutkan tenaga kerjanya pelatihan justru memiliki produktivitas yang tinggi di Kabupaten Barru dibanding IKM yang pernah mengikutkan tenaga kerjanya dalam pelatihan.

Adapun saran untuk hasil penelitian ini adalah :

Pemilik usaha perlu menambah stok modalnya agar produktivitas tenaga kerja dapat mendingkat. Akan tetapi, penambahan modal haruslah proporsi dengan penambahan input lainnya, seperti jumlah tenaga kerja. Selain itu, pemilik usaha perlu secara berkala mengikutkan tenaga kerjanya pada pelatihan-pelatihan yang materi pelatihannya mengikuti perkembangan pasar.

Pemerintah daerah perlu secara rutin mengadakan pelatihan dengan materi pelatihan yang lebih varian atau tidak monoton dan mengikuti perkembangan pasar. Selain itu, follow up setelah pelatihan terhadap tenaga kerja IKM harus dilakukan. Pemerintah daerah perlu pula membantu pelaku-pelaku IKM di Kabupaten Barru dalam hal penyediaan modal atau sarana prasarana yang mendukung produksi IKM di Kabupaten Barru.

\section{DAFTAR PUSTAKA / REFERENCES}

Adhadika, T. 2013. Analisis Faktor-faktor yang Mempengaruhi Produktivitas Tenaga Kerja Industri Pengolahan di Kota Semarang (Studi Kecamatan Tembalangdan Kecamatan Gunungpati).Skripsi tidak diterbitkan. Semarang : Fakultas Ekonomikadan Bisnis Universitas Diponegoro. 
Afifah, R. Z. 2012. Analisis Bantuan Modaldan Kredit Bagi Kelompok Pelaku Usaha Mikrooleh Dinas Koperasidan UMKM Kota Semarang (Studi Kasus: KPUM di Kelurahan Pekunden, Kecamatan Semarang Tengah).Skripsi tidak diterbitkan. Semarang: Fakultas Ekonomikadan Bisnis Universitas Diponegoro.

Antari A. A. I. I. D., dan Widanta, A. A. B. P. 2016. Determinan Produktivitas dan Penyerapan Tenaga Kerja pada Industri Perak di Kabupaten Klungkung. E-Jurnal Ekonomi Pembangunan Universitas Udayana, Volume 5, Nomor 9.

Ariani, N.W.D.,Suresmiathi, A.A.A. (2013). Pengaruh Kualitas Tenaga Kerja, Bantuan Modal Usaha dan Teknologi Terhadap Produktivitas Kerja Usaha Mikro Kecil dan Menengah (UMKM) Di Jimbaran. E-Jurnal EP Unud, 2 [2], 102-107.

Baharuddin, Eva. 2008. Analisis Kesenjangan Ekonomi antar Kabupaten/kota di Provinsi Gorontalo. Artikel http://repository.unhas.ac.id.

Deliarnov. 2012. Perkembangan Pemikiran Ekonomi. Jakarta: RajaGrafindo Persada.

Gujarati, Damodar, Dawn C. Porter. Dasar-dasar Ekonomterika. Terj. Eugenia. Mardanugraha, dkk. 2010: Jakarta.

Hamzah, Suharwan. 2013. Pembangunan Ekonomi Kerakyatan Berbasis Komoditi Unggulan Kabupaten Polewali Mandar. Artikel http://repository.unhas.ac.id

Herdiansyah, R. 2011. Pengaruh Pengalaman Kerja dan Tingkat Upah Terhadap Produktivitas Pekerja di UD. Farley's Kota Mojokerto. Skripsi tidak diterbitkan. Surabaya : Fakultas Ekonomi Universitas Negeri Surabaya.

Hussein, M. Z. 2014 dalam http://indoprogress.com/2014/02/produktivitas-riil- dan imbalan-riil-buruh/

Kurniawan, G. 2010. Analisis Faktor-faktor yang Mempengaruhi Produktivitas Tenaga Kerja pada PT. Kalimantan Steel (PT. Kalisco) Pontianak. Jurnal Manajemen Universitas Muhammadiyah Pontianak.

Mankiw, N. G. 2007. Makroekonomi. Jakarta: Erlangga.

Mustofa, P. 2013. Peran Kredit dari Koperasi Serba Usaha (KSU) "Artha Sukses" Terhadap Perkembangan Usaha Mikro yang Menjadi Anggotanya di Kota Semarang.Skripsi tidak diterbitkan. Semarang: Fakultas Ekonomikadan Bisnis Universitas Diponegoro.

Samuelson, P. A. dan Nordhaus, W. D. 2003. Microeconomics.New York: McGraw-Hill.

Sambodo, I. A. 2016. Pengaruh Pelatihan Terhadap Produktivitas Kerja Karyawan pada PT. Waskita Karya (PERSERO) TBK Cabang Sulawesi. Skripsi tidak diterbitkan. Makassar: Fakultas Ekonomik dan Bisnis Islam UIN Alauddin.

Sarwono, J. 2006. Metode Penelitian Kuantitatif dan Kualitatif. Yogyakarta: Graha Ilmu.

Sihombing, D. 2009. Analisis Pengaruh Faktor Produktivitas Tenaga Kerja di Kabupaten Dairi, Provinsi Sumatera Utara, 1993-2003. Jurnal Kependudukan Indonesia Volume IV, Nomor 1, 1-13.

Sinungan, M.1995. Produktivitas Apa dan Bagaimana. Jakarta: Bumi Aksara.

Simanjuntak, P. J.2001. Pengantar Ekonomi Sumber Daya Manusia edisi 2001. Jakarta: Lembaga Penerbit Fakultas Ekonomi Universitas Indonesia. 
Volume 5 Nomor1 Ed.Juni 2018 : page $80-98$ p-ISSN: 2407-6635 e-ISSN : 2580-5570

Sulaeman, A. 2014. Pengaruh Upah dan Pengalaman Kerja terhadap Produktivitas Karyawan Kerajinan Ukiran Kabupaten Subang. Jurnal Ekonomi Trikonomika, Volume 13, Nomor 1, 91-100.

Suprayitno, B., Nurseto, T., Supriyatno. 2017. Produktifkah Human Capital Investment Oleh Pemerintah Daerah Provinsi Dalam Era Desentralisasi? Jurnal Economia, Volume 13, Nomor 1, 39-55.

Yeni, N. T. A. dan Budhi, M. K. S. 2016. Analisis Faktor-faktor yang Mempengaruhi Penyerapan Tenaga Kerja dan Produktivitas Kerja Patung Kayu. E-Jurnal Ekonomi Pembangunan Universitas Udayana, Volume 5, Nomor 4.

Yuniasih, A. F., Firdaus, M., Fahmi, I. 2013. Disparitas, Konvergensi, dan Determinan Produktivitas Tenaga Kerja Regional di Indonesia. Jurnal Ekonomi dan Pembangunan Indonesia Volume 14, Nomor 1. 